\title{
LEGAL PLURALISM AND INTERNATIONAL DEVELOPMENT: INTRODUCTORY NOTES ON THE DIALOGUE BETWEEN THE TWO CONCEPTS.
}

Miguel de Lemos ${ }^{1}$

\section{Abstract}

This study is based on the dialogue between legal pluralism and international development, which shapes the daily lives of much of the world population, in particular those who live in emerging or developing States and are subject to programmes of international technical assistance. Due to a number of factors, this dialogue is required to, on a practical level, harmonise diametrically opposed onto-epistemological legal dimensions. From the epistemological point of view, the phenomenological dimension of this study will allow us to analyse the conceptual and scientific evolution of both legal pluralism and international development, accompanying the development of the underlying legal theory which, in cycles, has seen moments of convergence and divergence, and of tension and distension, over the last seven decades. Having as background the case study of Timor-Leste this work also looks at the practical consequences that certain options will give rise to in building a State and its systems of justice within the framework of legally plural societies.

Keywords

Legal Pluralism; International Development. Modernisation Theory. Law and Development Movement. Rule of Law. Timor-Leste (East Timor).

\section{Summary}

1. International Development: Modernisation Theory and the Law and Development Movement. 2. The Renaissance of Legal Pluralism in the context of International Development. 3. International Development and Legal Pluralism: From Industry to New Paradigms. 4. References.

1 Lecturer, Faculty of Law, University of Lisbon. 


\section{INTERNATIONAL DEVELOPMENT: MODERNISATION THEORY AND THE LAW AND DEVELOPMENT MOVEMENT.}

With the end of World War II and on account of the first breezes of the winds of change that led to decolonisation movements on a global level, the now international community - gathered around the United Nations - and in particular, the western $b l o c^{2}$, found itself committed to promoting Statebuilding operations all around the world. These operations, within the context of self-determination movements, would enable 1) the practical implementation of independence and 2) the blunting of the differences between the West - i.e. the developed countries - and the other regions of the globe, which, due to political, cultural and economic models that were themselves a result of European colonialism and also their historical constraints, had been labelled as under-developed.

To understand international development, in particular in terms of legal institutions, at this specific moment in history, we need to consider a theoretical and ideological background that was marked by the American political situation of the time. With the constraints on its hegemony imposed by the Cold War as a backdrop, America was competing to export its own model of political and economic development to emerging countries ${ }^{3}$ - a

2 Due to historical changes, namely the fact that many of the countries in this bloc had colonies that were now setting out on their path to independence.

3 This was, in fact, the tone set for foreign policy by American president Harry Truman in his inaugural speech, where he used his fourth point to place development on the agenda, and the USA's role in promoting it:"[...] Fourth, we must embark on a bold new program for making the benefits of our scientific advances and industrial progress available for the improvement and growth of underdeveloped areas. [...] Their economic life is primitive and stagnant. Their poverty is a handicap and a threat both to them and to more prosperous areas. [...] The old imperialism, exploitation for foreign profit, has no place in our plans. What we envisage is a program of development based on the concepts of democratic fair dealing. [...] Democracy alone can supply the vitalizing force to stir the peoples 
model which, in institutional terms, was interdependent on the rule of law and, in conceptual terms, was based on modernisation theory ${ }^{4}$.

This theory sought to explain, among others, the process of development of human communities. Despite not being new in the history of Western thought - as ROBERT NISBET points out, noting this type of reflection from Classical Antiquity to modern times ${ }^{5}$ - its originality lay in the use of the concept of development - whether this is understood as aspiration, ideology or field of study ${ }^{6}$ - to fill a gap that had existed up to that point, this being a lack of a general theory of socio-economic progress, particularly regarding its consequences for the development of society.

This theory, with its openly universalistic aims, had to be capable of serving as an explanatory model and, moreover, a programmatic - technical-political route map for development, also seeking, in the words of SAMUEL P. Huntington, to respond to the Great Dichotomy between primitive and developed societies ${ }^{7}$.

In the light of the above, modernisation theory would present a non-Marxist, macro-sociological and interdisciplinary framework, although the key aspects explaining societal change fell almost entirely within an economic monocausality. Modernity was considered to be linked to an increase in social differentiation - which itself is due to reasons scientifically located in the field of Economics - and this would lead to the appearance of political, economic

of the world into triumphant action, not only against their buman oppressors, but also against their ancient enemies hunger, misery, and despair. [...]". TRUMAN 1949. Vide, also, GARDNER 1980.

4 Vide KNÖBL apud DELANTY and IsIN 2003, 96 et seq.; TAMANAHA 1995, 471 et seq.; HUNTINGTON 1971, 285 et seq.; APTER 1987.

5 NisBet 1969, 13-137.

${ }^{6}$ BERNSTEIN 1971, 142.

${ }^{7}$ Huntington 1971, 285. 
and social institutions similar to those that were characteristic of the West ${ }^{8}$. Evolution was, thus, understood as a uniform, linear and irreversible process.

It is not possible to point to one canonical work of modernisation theory, since the theory is, rather, a relatively vast and vaguely homogeneous collection of individual contributions from authors connected, as we have seen, to a wide range of fields of knowledge. Nevertheless, the influence of the sociological work by the American MARION J. LEVY 9 is undeniable. LEVY was concerned with producing a macro-sociological study of development, and took as a starting point some ideas put forward by TALCOTT PARSONS, in particular, structural-functionalism and pattern variables ${ }^{10}$ - the founding notions of post-war sociology - as well as including within his theoretical model, in the words of BRIAN TAMANAHA : "[...] familiar dichotomies found in social theories of Durkheim, Weber, Tönnies and Parsons, involving the shifts from particular to universal, from ascription to achievement, and from affectivity to affective neutrality - all of which purportedly accompanied the functional differentiation of society" ${ }^{11}$.

Thus, if we consider its descriptive aspect, modernisation theory was based, methodologically, on ideal-type dichotomies, starting from that previously referred to - which opposes the traditional and the modern - and extrapolating a range of other antitheses that enable justification of not only the starting point but also the evolutionary progression of societies ${ }^{12}$.

8 TAMANAHA 1995, 471.; APTER 1987.

${ }^{9}$ Vide LEVY apud HOSELITZ 1963, 113-125.

${ }^{10}$ Note that TALCOTT PARSONS was himself and apologist of modernisation. Vide MAYHEW 1984. PARSONS 2005. PARSONS 1982, 106 et seq.

11 TAMANAHA 1995, 471.

12 Thus, in the words of BROWN, "Tradition becomes by definition the dark past left bebind in a mythic narrative of progress. The political point of narrative arrival is the state, particularly the modern liberal state, and the dichotomy of irrational tradition and enlightened modernity is embedded in popular representations of the state" in BROWN 2014, 112. 
It is, therefore, paradoxical that modernisation theory, despite appearing in the second half of the twentieth century as a reflection of the post-war spirit of optimism, yet returns to the previous century to find support in the legal thought of the theoretical constructions of the Grand Process of Modernisation, and, therefore, overlooking relevant contributions - which, at the time, had appeared just a few decades earlier - in particular in the area of social and human sciences, still regards society as "[...] moving in response to essentially economic causes through an identifiable sequence of ever more beneficent phases [...]"13.

Indeed, in the simplistic terms expressed, this evolution would be achieved by moving away from traditional societies dominated by a model of functional diffuseness with, in the words of MAX WEBER, traditional or charismatic mechanisms of legitimisation of authority ${ }^{14}$, that is, mechanisms conditioned by the personal attitudes of their leaders, marked by particularism and by axiological frameworks which, when transposed into State decisionmaking and governance processes - necessarily of a Western, Westphalian nature - tend to be considered irrational and barriers for economic and political development ${ }^{15}$.

Now, and from an ideal-type perspective, these societies would have to evolve, organically reaching a model of structural functionalism, as argued by TALCOTT PARSONS, in which, as a coherent - undivided - whole, they would base their

13 Huntington 1971, 292.

14 Traditional authority, based on relationships of personal loyalty, in which, although there are no formal principles for the exercise of power, the unity of social context, which makes this model viable, derives from a set of obligations based on tradition, which allows a type of autocratic, despotic and arbitrary authority, which the author classifies as non-rational. Vide WEBER 2012, 241 et seq. Regarding charismatic authority, this "[...] is specifically irrational in the sense of being foreign to all rules", that is to say, in the sense that it is not linked either to a legalistic model, understood here in Weberian terms, or to tradition. It is, in this sense, an absolutely erratic and unpredictable power. Idem, 358 et seq.

15 KNÖBL apud DELANTY and ISIN 2003, 97-98. 


\section{Miguel de Lemos ILEGAL PLURALISM AND INTERNATIONAL DEVELOPMENT I ISSN 2675-1038}

evolutionary paradigm on individualistic, secular, scientific and rational values, moving, by this means, towards the Weberian model of legal authority ${ }^{16}$.

Yet, as WOLFGANG KNÖBL argues, when bringing MARION J. LEVY's conceptualisation to the fore and noting that the latter achieved the "historicization of the "pattern variables" [also being] able to encompass Max Weber's ideas concerning the process of occidental rationalization, to clarify Ferdinand Tonnies' crude dichotomy between Gemeinschaft and Gesellschaft or Émile Durkheim's distinction between "mechanical" and "organic solidarity" 17 , that conceptualisation is not, from the author's perspective, immune to criticism. This is particularly true due to Levy's linear view of historical progress and his simplification of the theories he employs, allowing him to standardise and make compatible a range of premises based, we repeat, on ideal-types, which - while giving substance to modernisation theory - would otherwise not be reconcilable ${ }^{18}$.

It is, then, in this context that modernisation theory tends to stray from the theoretical constructions of the early $20^{\text {th }}$ century - marked by a pessimistic zeitgeist, the result of the political, economic and social transformations of the time - returning instead to the evolutionary optimism of the previous century $^{19}$. As a consequence, in particular in the legal field, it tended to distance itself from new understandings in legal thought - enriched by the contributions of recent ancillary subjects, such as legal anthropology and sociology of law - which were taking their first steps towards a broad and

16 WEBER 2012, 241 et seq. Thus, as HUNTINGTON argues, "The simpler theories of modernization implied a zero-sum relation between the two: the rise of modernity in society was accompanied by the fading of tradition" in HUNTINGTON 1971, 295.

17 KNÖBL apud DELANTY and ISIN 2003, 98.

18 KNÖBL apud DELANTY and ISIN 2003, 99.

19 Note also, following WALT ROSTOW, that such a theoretical position also made it possible to anchor the explanations and premises of modernisation theory in the light of a bistorical reading, namely the European - Western - uniqueness of global development and expansion. Vide RosTOW 1971; passim. In the same sense: GONG 1984. 
comprehensive view of the Law, with some of them going so far as to reject legal formalism ${ }^{20}$. Thus, the notion of exporting the legal model in the post-war period is the fruit of that 19th century thought, a centralising force based on the rule of law, or in other words, resulting in rejection of the eminently plural nature of law. This understanding, having succeeded in Western countries, due to their own vicissitudes and historical constraints, was now exported, in a state building/rule of law package, all around the world.

It is precisely on this point, now taking into account both the descriptive aspect of modernisation theory and its programmatic aspect, with its undeniably universalistic social engineering purposes - to spread Western modernisation - and the aim of responding to the political need for cohesion, namely decolonisation and subsequent State building, that we begin to witness the first difficulties. These difficulties relate particularly to the impossibility of dialogue between the framework to be implemented - in certain cases, imposed - and the indigenous systems that would be removed and subjugated by a modern paradigm - also corresponding to a modern law model $^{21}$ - oftentimes incompatible with a modus vivendi characterised as traditional ${ }^{2}$.

In fact, in this period, the urgency which many of the international development projects tended to afford modernisation, with the goal of legitimising the power of the new post-colonial authorities, namely through the Weberian model of legal authority, led to a focus on skipping or accelerating evolutionary stages in a simplistic syllogism - completely detached from reality - in which isomorphic transposition of an institutional model

${ }^{20}$ In the particular case of the USA: "[...] the US rhetoric of the rule of law did not account for the complexity of American legal thought at the time, which, since the 1930s, was in the thrall of legal realism and a form of instrumentalism. American legal realism was a response to legal formalism in that it emphasised the gap between "law on the books" and "law in action" and it introduced sociological elements focusing on the process of law." GRENFELL 2013, 19.

21 GALANTER apud WEINER 1966, 153 et seq.

22 "[...] these projects often encounter huge difficulties because of unfamiliar social structures and cultural patterns" in KNÖBL apud DELANTY and ISIN 2003, 97. 
- in the broad sense, also understood to mean one Law - would give rise to economic development which, in turn, would lead to social development.

It was in this context and by this means that the Law and Development Movement emerged. Through this movement scholars would attempt to respond to and theorise on issues resulting from the relationship between Law - understood in both its normative and institutional aspects - and the new and, to some extent, divisive premises of international development and modernisation theory ${ }^{23}$. Thus, the attempt to provide the new countries with models of justice that could respond to the - previously unseen Westphalian model of the State, namely the centralisation of power and the need, in this context, to shift the legitimisation of power from traditional justification to legal justification ${ }^{24}$, gave rise to the following question: which Law should be applied/put forward? ${ }^{25}$

23 As a very brief introduction, vide RITTICH apud CANE and CONAGHAN 2008, 677 and 678. The Law and Development movement was based, according to DAVID TRUBEK, on four key pillars: a cultural reform and transplantation strategy; an ad hoc approach to reform based on simplistic theoretical assumptions; faith in spillovers from the economy to democracy and human rights; and a development strategy that stressed state-led import substitution." in TRUBEK and SANTOS 2004, 78.

24 "The law-and-development movement adopted the basic tenets of modernization theory, adhering to the notion that evolutionary progress would ultimately result in legal ideals and institutions similar to those in the West." in TAMANAHA 1995, 473.

25 GRENFELL 2013, 19. Also, "The Law and Development movement began in the United States in the 1960s. This was a fateful origin because North America did not have a notable history of colonial administration and, therefore, had not had much occasion to ponder the role of law in development. By comparison, European nations were far more experienced by necessity in dealing with such matters due to their colonial pasts. This does not mean that their thinking reflected a strong theoretical basis. Nonetheless, the colonial administrations of the British Empire, the French colonies, and of course the Dutch Indies, East and West had for years dealt with a variety of legal challenges where, although the colonial-era lawyers in Batavia, British East Africa, Afrique Occidentale Française and Afrique Équatoriale Française did not worry about the use of law in colonial development, they certainly exercised it." in ARNSCHEIDT, ROOIJ, and OTTO 2008, 25. 
No immediate answer could be provided, but within the scope of scholarly discussions and studies during the 1950s, several paths were suggested for the development of legal systems that could meet the needs and particularities of the newly formed States.

One of these particularities arose from the very nature of the independence movements, which, legitimised by the, at the time, legal and political principle of the self-determination of peoples - a principle which would go on to gain the status of jus cogens in International Law - would find themselves limited in practical terms by the conservative principle of uti possidetis. This principle was responsible for maintaining the colonial geopolitical artificialism, crystallising, on the new world maps, artificial national situations ${ }^{26}$, and, for that reason, these nations were committed to promoting - as a condition for their recognition by the international community and for their own survival - a standardised model of institutional development which, thus, is confused with legal-political centralism.

Hence, in the urgency that accompanied the decolonisation movements, Law was seen, in functional terms, as one way to respond to and combat the dangers that pluralist developments might bring to these new geopolitical situations, namely tribalism and the resulting fragmentation of the territory.

In fact, in this period the aims and wishes of the new post-colonial political entities $^{27}$ - in particular their dominant elites - were aligned, for the reasons shown here, with those of the Western intelligentsia, who were committed, within the framework of modernisation theory, to rejecting legal pluralism. This was both because of its historical connotation, it being seen, in this sense, as a movement that aided European expansion and permanence in

26 LEMOS 2018, 45 et seq.

27 As SALLY ENGLE MERRY states: "[...] elites in Africa see modernization and nation-building as requiring a unified legal system, often drawing on models of European law" in MERRY 1988, 871. 
overseas territories - that is, as an instrument of colonial domination ${ }^{28}$ - but also because of modern conceptions of international development which, seeing Law from an instrumental perspective, leading to or favouring social engineering projects, thus rejected legal pluralism, imposing a model of modern, Western Law, focusing on the Weberian transition from the traditional to the legal model of legitimisation.

From a practical point of view, this means the Herculean task of implementing a generic set of international standards that go by the diffuse name of rule of law, based on centralised power systems, which tend to be democratic, from which laws emerge that are standard, published and organised in a system that promotes legal certainty. An instantaneous solution is required and one which, as we have seen, denies the evolutionary nature of the institutions and legislative solutions that are intended to be implemented ${ }^{29}$. It is a model, or a set of models, that are transposed - or transplanted - and which, through their ethnocentrism, also tend to ignore the specific situation of the receiving country ${ }^{30}$.

It should be noted, however - and this is a key aspect of the issue surrounding the relationship between development and legal pluralism, particularly in the context of emerging countries - that, on the other side of the looking glass, the communities, the populations of these countries themselves established socially and structurally on social pluralism - do not share, with regard to legal pluralism, either the position of their leaders or that of the development professionals with their corresponding modernising theoretical premises.

${ }^{28}$ MOMMSEN and DE MOOR 1992; passim. Vide, in particular, FISCH, 15 et seq..; REYNTJENS, 111 et seq. Also, BENTON 2002.

29 TAMANAHA 2004. BINGHAM 2011.

${ }^{30}$ CAROthers 2006, 19. 


\section{Miguel de Lemos ILEGAL PLURALISM AND INTERNATIONAL DEVELOPMENT I ISSN 2675-1038}

In other words, legal pluralism, or rather traditional, customary law, in the sociological dimension, is not seen as a problem ${ }^{31}$, and much less as an obstacle to be overcome in the daily life of populations, when we consider development. Development is, in fact, understood in a more prosaic way, in terms, for example, of the infrastructure or security aspect, or of access to health and sanitation, and promoting the isomorphism of Western justice systems is something that scarcely enters the worldview, concerns and immediate needs of these communities.

Accordingly, it is important to state that formal systems of justice, in postcolonial States, to which the most well-known aspects of the pre-existing situation are transferred - the buildings, iconography and liturgical and symbolic aspects of the judicial administration - rather than, we must stress, the technical-legal capacity ${ }^{32}$, may be "perceived as captured, corrupt, inefficient, or hostile" or engaging with them may require "traveling great distances, waiting in long lines, completing complex forms, enduring bumiliating treatment, and paying probibitively expensive fees, only to receive an unsatisfactory outcome [...]"33.

31 It seems relevant to bring to light the question posed by H. PATRICK GLENN, in which he asks whether legal pluralism - including customary/traditional realities - should be seen as a problem: "It appears impossible, however, to conclude that is a problem, because a problem generally is thought to be that which is amenable to solution or elimination. Legal pluralism appears to be rather the state of play, or the underlying default position of all laws [...]" in GLENN apud TAMANAHA, SAGE and WOOLCOCK 2012, 100.

32 This is the subject of development projects, in particular legal technical assistance, which, by way of example, at the same time is reflected in projects such as: "Providing judicial training as well as other forms of legal education for students and professions, assisting in commercial law drafting, promoting professional development such as helping to establish or bolster bar associations, belping to streamline the legal regulation of businesses, and alternative dispute resolution, access to justice and legal clinics are among the standard items on the menu of interventions [...]" in ARNSCHEIDT, ROOIJ, and ОтТо 2008, 23.

33 SAgE apud TAmAnaha, SAGE and WoOlCOCK 2012, 2. Note also, following GEOFFrey SWENSON, regarding post-conflict states: "Direct application of existing models of judicial state- 
Such a situation leads many emerging countries to reject the use of formal systems of justice, and recent studies have suggested that, on average, around 80 to $90 \%$ of disputes are resolved by informal means ${ }^{34}$ - such as traditional or customary law - thus rejecting the rule of law and, also, legal centralism ${ }^{35}$. Indeed, it is relatively easy to understand, in the light of the above, the reasons that guide people to choose the normative orders that are accessible to them, in the different aspects set out - geographical, financial and epistemological ${ }^{36}$ - and hence, also, their social efficacy and legitimacy.

These are the factors that produce the resistance that is felt, in developing countries, to many of the solutions brought to them via legal transplantation ${ }^{37}$ and modernisation and which, in a hierarchical logic, will be superior to the traditional systems. ${ }^{38}$

This is due, first of all, to the very nature of the technical-legal procedure, in which the legal systems and legislation are transposed, that is, as we suggested when alluding to their artificial instantaneity, without the contribution of historical, theoretical and cultural substrates, resulting from

building efforts presents serious problems because they do not recognize postconflict settings' systemic challenges." in SWENSON 2018, 441.

34 AlBRECHT and KYED 2010, 1.

$35 \mathrm{Vide}$, on this point, the various studies and bibliography cited by LAURA GRENFELL, in particular: "The UK's Department for International Development observes that, "in many developing countries, traditional or customary legal systems account for 80 per cent of total cases'"; adding: "according to Abdullabi Abmed Na-Na'im, customary law is the most important source of law for the majority of Africans", a study which the author bases on data collected, in 1997, in 15 African countries. GRENFELL 2013, 5-6.

${ }^{36}$ In the sense of a cosmogonic worldview proper to these populations.

${ }^{37}$ LEGRAND1997, 111-124.

38 "The very notions of "customary" or "traditional" or "indigenous" were creations of and reactions to colonization and post-colonization, in which the norms and institutions of indigenous societies were marked (for various purposes) as distinct from the transplanted norms and systems of the colonizers." TAMANAHA 2008, 397. 
a secular evolution and of which they are necessarily a product: "Our free institutions are the product of a long history, a gradual development from feudalism to landlordism and from landlordism to modern democracy. ${ }^{\prime 39}$

Stripped of their ontological-cultural component, Western transplants, particularly in a situation of competition, are set against ancestral legal realities that have been embedded in the founding structures of these communities - the family, the clan, and the tribe, among others - by means of proto-religious cosmogonies. These are organisational models of society which, unlike the West, have a fine line separating the public and private spheres, making it difficult for the populations to recognise the realities imposed upon them by a new political-normative dimension, based on a Law that derives, in evolutionary terms, precisely from this division ${ }^{40}$ and from the separation from moralising realities of a religious nature.

It was thus, and in the context we have been describing, within the framework of decolonisation and a model of legal engineering ${ }^{41}$ intended to be imposed by means of modernisation theory and, namely, the Law and Development movement, that the 1970 s witnessed rejection by development professionals of the traditional and customary systems of the countries subject to international intervention. This was true of both bilateral intervention and that occurring within the framework of multilateral agencies through International Development and State Building projects and projects promoting the rule of law, all of which, as we have seen, were not particularly inclined towards arguments that encouraged the promotion and safeguarding of indigenous cultural realities, including, naturally, legal traditions.

39 Taking the British situation as an example: JENNINGs 1956, 2-3.

40 Providing a detailed description, over two millennia, of the evolution of the separation between the public and private sphere within the scope of the evolution of the State, vide CREVELD 1999, passim.

${ }^{41}$ KÖNZ, PARRY and SHINDY 1969, 95. 
In fact, in the following decade, many of the development projects based on the Law and Development movement would see the financial support on which they depended come to an end, and consequently also witnessed the end of the movement itself. Added to the failures that were becoming commonplace all over the world - demonstrating the gap between objectives and results - were criticisms from Academia, which warned of a burning-out of the insipient and inadequate epistemological model - modernisation theory - on which the movement was based.

Highlighting the lack of a theoretical framework to shape the relationship between Law and Society and Law and Development ${ }^{42}$, criticism was also levelled at promotion of the (Western) legalist liberalism paradigm which, from a legalimperialist perspective ${ }^{43}$, superimposed an ethnocentric model on the local realities, ignoring their legal, institutional and cultural needs and specificities $^{44}$.

Moreover, since these development models were based, axially, on the State, from which the pursuit of all other objectives was derived, and given their fragility, particularly in the context of developing countries, being superseded, in power and legitimacy, by traditional systems - averse to the Westphalian model intended to be implemented - it is easy to understand why those projects failed.

2. THE RENAISSANCE OF LEGAL PLURALISM IN THE CONTEXT OF INTERNATIONAL DEVELOPMENT.

42 FRIEDMAN1969.

43 GARDNER 1980.

44 TRUBEK and GALANTER 1974, 1079 et seq. 
Thus, simultaneously and, to some extent, as a result of the decline of modernisation theory, a second wave ${ }^{45}$ of studies on legal pluralism emerged. As RALF SEINECKE highlights, this wave, since it does not appear in a scientifically pure space, must be seen in the light of the zeitgeist of the period - with its many influences and constraints ${ }^{46}$. In fact, following BRIAN TAMANAHA, this change of paradigm would embrace the ideological opposites of modernisation theory: "(1) blaming all the ills of developing countries on the imperialism of the West; (2) touting socialism over liberalism;" and, in particular, "(3) arguing that the cultures of developing countries had to be protected against the encroachment of Western values, especially by preserving local customs or ways of life from the expanding reach of state law."

Hence, in the last quarter of the twentieth century, we witness the (re)appearance of one of the most influential contemporary legal theories, legal pluralism, which, dichotomously and following the premise of JOHN GRIFFITHS - presented from a sociology of law perspective ${ }^{48}$, would affirm

45 This second wave follows studies on pluralism from anthropological and sociological perspectives on normative realities in a colonial context, realities that were opposed to or adapted to law originating from a Western, colonial framework. Thus, it should be noted that the direction of legal pluralism that gained traction in the 1970s emerged from these seminal studies - the so-called classical pluralism - rather than from the theoretical studies coexisting with the works by BRONISEAW MALINOWSKI, of a plural law studied in the context of modern society, as we have seen, through the works of EUGEN EHRLICH, GEORGES GURVITCH, or of legal institutionalism by MAURICE HAURIOU or SANTI ROMANO. On classical pluralism, vide, including the bibliography cited therein, MERRY 1988,869 et seq.

46 SEINECKE 2017, 216. In the same vein, BRIAN TAMANAHA, when referring to the obsolescence of modernisation theory and also the Law and Development movement. TAMANAHA 1995, 472.

47 TAMANAHA1995, 481.

${ }^{48}$ Note that "literature on legal pluralism has, by and large, arisen from sociologists of law (including legal anthropologists) and comparative lanyers. No leading liberal political theorist has bothered much about legal pluralism, let alone with the relative autonomy of the law in an analysis of the state [...]" in BAXI apud SACK and MINCHIN 1985, 51. 
itself as a fact - as a phenomenological reality -, dismissing legal centralism as a: "myth, an ideal, an illusion [...]"49.

Accordingly, and moving away from the unfortunate experience of the practical application of the Law and Development movement - which was due both to the ontological premises on which it was based ${ }^{50}$ and to the lack of efficacy of its projects in a wide range of geographies ${ }^{51}-$, legal pluralism, as the current legal thought, most vehemently rejected legal centralism and its basic principles, which, as we have seen, centre, in conceptual terms, around the concept of the State, its law and the claim of exclusivity of its production and application in a given time and space.

The factual reality, which results from the aforementioned theoretical vision, and which most scholars of legal pluralism adhered to - in the initial stages - is connected with the existence of legal orders that arise and operate outside the State, with their own mechanisms of legitimacy and authority ${ }^{52}$ - as we have shown in the context of post-colonial countries. The anachronistic legal dogma is set against informal socio-legal experiences, and, accordingly, a law with polycentric origins is proposed - as, in fact, had previously been done in the first decades of the $20^{\text {th }}$ century, although based on different grounds.

In this way, and refocusing the presentation on the application of these realities to emerging countries, we observe, with greater clarity, the notion of the "beterogeneous State" 53 put forward by BOAVENTURA DE SOUSA SANTOS, the main elements of which are "disjunction between the political and

${ }^{49}$ GRIFFITHS 1986, 4.

50 This movement "[...] focused on higher agencies of the legal system and showed little interest in nonstate forms of legal or other social ordering; indeed, one detects a subtle bias against legal systems and customary law" in TRUBEK and GALANTER 1974, 1079.

51 CAROTHERS 2006, 15 et seq.

52 WOODMAN apud Dupret, MAURITS and AL-ZWAINI, 1999, 10 et seq.

${ }^{53}$ SANTOS and TRINDADE 2005, 47 et seq. 
administrative control over the territory and its people, the lack of integration among different political and legal cultures governing state action and the official legal system, and political and institutional upheavals caused by multiple ruptures occurring in rapid succession." 54

We may note, however, that the author went further, using this concept as a starting point to support his post-modern vision of Law, marked by the previously mentioned interlegality and the overcoming of some of the dichotomies that we have referred to - traditional/modern; formal/informal; official/unofficial.

However, as we noted earlier, such a conceptual route, within the scope of our analysis, would become illogical and insipient in practical terms, since it is, precisely, in those dichotomies - and in the difficulty of managing them that we find the major theoretical and practical problem of the dialogue between legal pluralism and international development and not, we might add, in a more abstract reflection - which is how we understand the author's conceptualisation - which, by distancing itself from the field of sociology of law, tends to move closer to a philosophy of law conceptualisation, proposing, programmatically, a new way of thinking Law: a new post-modern legal dogma.

Therefore, despite a certain appearance of uniformity - resulting both from the ontological opposition of pluralism to legal centralism and from the attempt to capture, scientifically, the pluri-normative universe - it should be noted that, with the development of various studies, during the course of the 1970s, new perspectives and theorisations began to emerge, leading JACQUES VANDERLINDEN to state "Ily a autant de pluralismes juridiques qu'ily a aujourd'bui de personnes qui s'y intéressent"

54 SANTOS and VAN DÚNEN 2012, 57.

55 VANDERLINDEN 2013, 235. 
Interpretation of this premise leads us, firstly, to the bistory of the conceptualization of legal pluralism, which, as a result of contributions from different legal sub-disciplines, with their own methodologies, necessarily took a plural route, being used, as a concept - and as a research model - with different scopes and purposes. We can see, in this respect, as we have shown, the evolution from the classical notion that emerged from seminal studies in the field of legal anthropology and sociology of law - with a markedly empirical framework and in the colonial context - to more recent studies on the new pluralism, which, on a theoretical level, suggests a new perspective on the normative theory ${ }^{56}$.

In fact, in either case, what we see is a tendency to commit the same methodological error - the same original $\sin ^{57}$ - of legal positivism, which was also at the heart of the monistic conception of Law: i.e. the attempt to build an aggregating general theory, now applied to a situation which, being by its very nature plural, is not subsumable within a single theoretical model: "[...] legal pluralism as a way of theorizing the legal must itself be pluralistic, [...] it cannot be contained in the form of a one-dimensional legal theory" 58 .

In spite of the above, given the scope and, necessarily, the limitations of this work, it will not be possible for us to digress into what is already a very rich and diverse theorisation of legal pluralism, or the question that underlies it - we would say, even ontologically - and which is related to the definition of the legal phenomenon - of Law - in the context of a sometimes difficult dialogue between normative realities. "Fortunately,", as BRIAN TAMANAHA states, "it is not necessary to construct a social scientific conception of law in order to

${ }^{56}$ Merry 1988, 879.

${ }^{57}$ An expression we have borrowed from VASCO PEREIRA DA Silva. Silva 2005, 9 et seq. ${ }^{58}$ Melissaris 2009, 26. 
frame and study legal pluralism. [...] Legal pluralism exists whenever social actors identify more than one source of "law" within a social arena"s9.

Starting from a legal realism perspective, we believe it is important to stress that a sociology of law approach has been adopted in relation to this study, which, through its own methods of analysis, and when compared to the Science and Theory of Law, provides a broader and more dynamic perspective of what Law is, considering the problems of its scope of application rather than merely limiting itself to the centralized and centralizing vision of the production of legal rules within the framework of State institutions ${ }^{60}$. Thus, in a non-exclusive way and analysing the situation empirically, this approach juxtaposes the law thus produced - the official law - with a plural reality, which is necessarily more diffuse and which, in the words of JOSEPH RAZ, is reflected in "other kinds of law"

In view of the above, and alluding to the diachronic approach that we have been taking, in answer to the practical question that seems to result from a certain schizophrenia of the legal phenomenon - when understood in a certain time and space - in which parallel realities, the formal and the informal, compete for their solutions to be applied, this situation being more apparent in fragile, emerging and post-colonial countries, it seems pertinent to invoke the definition of legal pluralism which, from a sociology of law perspective, is brought to us by JOHN GRIFFITHS, and with which he closes his seminal article What is Legal Pluralism?.

59 TAMANAHA 2008, 36.

${ }^{60}$ As he argues, in the methodological position he takes on the subject, "[...] I find a concept of law that is not linked to the state by definition and that is broad enough to include "legal pluralism" a useful sensitising and analytical tool." in BENDA-BECKMANN 2002, 40.

${ }^{61}$ RAZ 2014, 1. "Even though much of legal philosophy takes state-law as its starting point, writers are aware of the existence of other kinds of law, and I do not mean laws of nature, mathematics or grammar. I mean laws that are uncontroversially normative.". Idem, 3. 
In a view already considered classic, the author defines legal pluralism as the situation in which "[...] law and legal institutions are not all subsumable within one 'system' but have their sources in the self-regulatory activities of all the multifarious social fields present, activities which may support, complement, ignore or frustrate one another, so that the 'law' which is actually effective on the 'ground floor' of society is the result of enormously complex and usually in practice unpredictable patterns of competition, interaction, negotiation, isolationism, and the like" ${ }^{\text {"62 }}$.

In this sense, and since these realities are necessarily separate from each other, maintaining, in the words of GORDON WOODMAN, "separate and distinct sources of content and legitimacy" ", the relationship between formal legal systems, those resulting from the imperative law of the State, and other situations considered informal, traditional or customary, in other words extra-State, may, to use UPENDRA BAXI's classification, be divided into four types: symbiotic or complementary - opening the door to bybridisation ${ }^{64}$ - or

${ }^{62}$ GRIFFITHS 1986, 39. Alongside this definition, we may propose others: WiLLIAM TWINING, who makes a point, in his studies, of reiterating the difference between normative pluralism and legal pluralism, defining the latter as a set of "legal systems, networks or orders co-existing in the same geographical space." in TWINING 2000, 83 et seq.. From the same author, vide, also, TWINING 2009. For his part, JACQUES VANDERLINDEN defines legal pluralism as "[...] l'existence, au sein d'une société déterminée, de mécanismes juridiques différents s'appliquant à des situations identiques." in VANDERLINDEN 1971, 19. BRIAN TAMANAHA, in the work dedicated to legal pluralism and international development, defines legal pluralism as "[...] a context in which multiple legal forms coexist" in TAMANAHA, SAGE and WOOLCOCK 2012, 34. SALLY ENGLE MERRY, summarising the state of the art suggests that legal pluralism is "generally defined as a situation in which two or more legal systems coexist in the same social field." in MERRY 1988, 870. The definition, as the author herself indicates, is a result of the work of LEOPOLD POSPISIL 1971; JOHN GRIFFITHS 1986 and SALLY FALK MOORE, that proposes the notion of "semi-autonomous social fields" in MOORE 1973, 719 et seq...

${ }^{63}$ WOODMAN apud DUPRET, MAURITS and AL-ZWAINI 1999, 10 et seq.

${ }^{64}$ Vide JAyASURIYA apud TAMANAHA, SAGE and WOOLCOCK 2012, 34. 
antagonistic or hegemonial-, generally the systems derived from the State and the centralist ideology ${ }^{65}$.

Given the above Timor-Leste can be considered an example of the dialogue between Legal Pluralism and International Development. There legal pluralism is based on the ambivalence between legal centralism, necessarily associated with the State ${ }^{66}$, and a very rich and omnipresent traditional or customary normative reality, and the relationship between them - assessed in caso - may be contained in the different categories proposed above.

It should be noted, however, that giving an account of the normative order of Timor-Leste also requires us to invoke a layered reality, a normative palimpsest, which allows us to scrutinise the influences of the various legal cultures that the territory has been subject to over the centuries, and which have shaped - and continue to shape - its legal-sociological experience ${ }^{67}$.

${ }^{65}$ BAXI apud SACK and MINCHIN 1985, 52.

${ }^{66}$ In the light of the above, and giving the specific example of the country, LAURA GRENFELL argues that "international actors promote the belief that a state with functioning rule-oflaw institutions is superior to all others and they cast the absence of the rule of law as the source of a host of ills, including social and political instability and international buman rights violations." in GRENFELL 2009, 213. Nevertheless, by placing the perspective of the problem thus and in the specific context of the first decade of post-independence, in the field of action of the international organisations present in the country at the time, in our opinion, the author presents a reductive vision that tends to omit the very history of the territory. Thus, from the time Portugal's intention to grant independence to all its overseas territories became public, in 1974, until the exercise of Timorese self-determination was frustrated, due to the intervention and invasion of the territory by Indonesian forces, in 1975, the constitution of $a$ Timorese state - a Westphalian state - was always a guiding element - the ideal to be achieved - from the 24 years of Resistance which, in external and diplomatic terms - and in the light not of the traditional/customs reality but of the systematic abuses of the Indonesian military forces - internalised that centralising, state-based discourse and that, because it offered a guarantee, was based on the rule of law.

${ }^{67}$ Thus, starting from a basic element, which we can call customary/traditional - that was also heterogeneous due to different, ethno-linguistic realities - other political and legal 
On this point, in a recent study on Justiças Comunitárias in Timor-Leste ${ }^{68}$, it is argued that the different political and legal cultures that have shaped the aforesaid Timorese palimpsest, "appear, with different degrees of intensity, in the Timorese legal and political reality, rather than it being implicitly assumed that the sociolegal reality in Timor is based on the modern/traditional binomial, as it is frequently described" ${ }^{\prime 69}$.

Without denying the different degrees of intensity with which the various legal phenomena made their mark, we must identify the conceptual framework underlying the study - the aforementioned so-called Coimbra school which promoted the idea of interlegality and, also, put forward a post-modern vision of $\mathrm{Law}^{70}$, doing so, in our view, in a context which, from a phenomenological point of view and from a careful factual analysis, using a sociology of law approach, points in the opposite direction. It seems to us, moreover, that - regarding the point we have identified - that study is lacking in specifics, in particular empirical facts to support its conclusions ${ }^{71}$, and therefore does not enable us to conclude that the modern/traditional binomial has been overcome in East Timor.

cultures were superimposed, from the first contacts with the regional empires or with Arab and Chinese cultures, up to the Dutch and Portuguese European presence, the latter uninterrupted for centuries with the exception of Japanese martial administration during the Second World War - vide HägERDAL 2012. GunN 1999. Following Portugal's departure from the territory, the Indonesian normative presence subsequently arose. This was considered illegitimate both by the population and by the international community and competed with the customary law and normative system of the Timorese military reintegration, ending with the UN mandate, through the United Nations Transitional Administration in East Timor (UNTAET). Lastly, this was superimposed by the normative system of an independent Timor-Leste, as well as that inherent to its responsibilities, imposed within the scope of the international community.

${ }^{68}$ Meneses ET Al. 2017.

${ }^{69} \mathrm{Idem}$, p. 36.

${ }^{70}$ SANTOS 1987, 297.

${ }^{71}$ This is the case, in particular, of pages 45 et seq. in MENESES ET AL. 2017. 
This is, in fact, - we continue to state - the axial explanatory model of the Timorese legal system, since we believe that the influences that we have noted, which have overlapped to constitute the Timorese palimpsest, and which have been particularly acute in what we might call formal/official Law - in each period - have had very limited action with regard to the customary/traditional dimension that, over time, has proved resistant to the changes directly proposed by these means.

To illustrate the situation of legal pluralism in Timor-Leste, LAURA GRENFELL, an author who is widely cited in the aforementioned study and who is heralded, in several works, as an expert in the legal pluralism of Timor-Leste, wrote in her work Promoting the Rule of Law in Post-Conflict States: "in Timor-Leste, apart from customary laws in each district and the national laws passed by the Government and Parliament of Timor-Leste, the individual must also contend with the ambiguity surrounding the applicability of laws of Portugal, its former coloniser, Indonesia, its former occupier, the Regulations issued by the UN, its former administrator, and international laws incorporated through constitutional provisions" ${ }^{\prime 72}$.

The author's intention seems to be to transmit a pluralistic normative law dynamic of Timor-Leste, which, being so complex, borders - in our interpretation - on an environment of legal chaos. In our view, such considerations are only possible if we obscure the intra-systematic legal mechanisms, which have been, from the beginning, post-independence, an integral part of formal Timorese law and which allow for a dynamic functioning, responding, in a systemic framework, to the previously presented relatively complex palimpsestic normative reality.

Given the above, the author's proposal regarding Portuguese legislation in particular ought to be rejected, since "Law no. 2/2002, of 7 August, while invoking the independence proclaimed in 1975 and simultaneously the need for a statute to facilitate the interpretation of the law received, establishes that the legislation in force in

72 Grenfell 2013, 60. 
Timor-Leste on 19 May 2002 [the eve of the country's independence] remains in force, with the necessary adaptations, in all that does not prove to be contrary to the Constitution and the principles enshrined therein. Subsequently, Law No. 10/2003, of 10 December, on the interpretation of Article 1 of Law No. 2/2002 of 7 August 2002 and sources of law, clarified that the legislation in force on 19 May 2002 should be understood as: all Indonesian legislation that was applied and in force "de facto" in Timor-Leste prior to 25 October 1999 [the date on which the UNTAET was established], as provided in UNTAET Regulation No. 1/1999",73.

In other words, apart from the legal effects of relations that had been created under Portuguese law, namely, by way of example, those relating to Family Law, we consider incorrect and misleading the reference to ambiguity regarding the application of "the laws of Portugal".

If any ambiguity does exist, it is not related to the Timorese legal system, an expression that we use, in a strict, technical-legal sense, to refer to the Law emanating from official bodies, hierarchically and systematically organised, but rather to the extra-systematic reality resulting from the simultaneous application of customary or traditional law. Thus, we reiterate that the core of the issue of Timorese legal pluralism is based on legal dualism, on the binomial that sets the modern legal component against the traditional one ${ }^{74}$.

It is therefore relevant to call on JOHN GRIFFITHS' conceptualisation of the relationship between pluralism and legal centralism, in which two currents can be extracted from the two-sided vision put forward: one which advocates

${ }^{73}$ Vide, in detail, PIRES 2005.

74 In the same sense, vide MEARNS 2002. "Although East Timor has come under Portuguese and Indonesian rule traditional legal systems have maintained their local dominance. Such systems, in which ancestral powers are the dominant forces, prioritise social reconciliation in order to maintain community harmony. The prevalence of such systems, combined with a lack of recognition of their importance on the part of the UN, has been a feature of the post-conflict phase." in HOHE and NIXON 2003, 1. JERÓNIMO 2011, 97 et seq. 
the existence of a strong pluralism and the other which, in turn, is based on an archetype of weak pluralism.

In relation to the first, following the author, we have " $a$ sort of situation [in] which [legal pluralism] is morally and even ontologically excluded by the ideology of legal centralism" "75, in other words, we have a parallel normative universe in which unofficial law - in our case, customary or traditional law ${ }^{76}$ - exists without there being any type of formal relationship between the two normative orders. There is no recognition, and neither is that reality regulated by the State "law is therefore neither systemic nor uniform" "77. With regard to weak pluralism, also known as state legal pluralism, not only is there a relationship between the various normative activities, but also parts of customary or traditional law are incorporated and thus systematised in the legal order of the State. Hence, "in this ("weak") sense a legal system is "pluralistic" when the sovereign (implicitly) commands (or the Grundnorm validates, and so on) different bodies of law for different groups in the population", and legal pluralism is "justified as a technique of governance on pragmatic grounds" ${ }^{78}$.

It is, in fact, in this model - a hierarchical model - that, either by means of subordinate recognition of custom, the codification of certain legal realities or of those considered to be proto-legal realities outside the State, or even by annexing to its apparatus certain realities of customary administrative or

75 GRIFFITHS 1986, 5.

76 It should be noted that, by methodological facilitation, we bundle a diverse and heterogeneous set of normative realities under the umbrella mantle of traditional or customary, the trademark of societies in emerging or post-colonial countries. In modern societies, the same division can be suggested. On this, vide MERRY 1988, 870 et seq.

77 GRIFFITHS 1986, 5.

${ }^{78}$ GRIFFITHS 1986, 5. This is, in fact, the historical meaning that M.B. HoOKER gave to pluralism, influencing, regarding the historical framework, a whole generation of academics who dedicated themselves to classical legal pluralism. Vide HOOKER 1975, 61 et seq. 
judicial organisation, we gradually see strengthening of the centralist State model and of its now appropriated Law.

This framework, as we have seen, was widely challenged in the defence of strong pluralism, which, emerging in the 1970s, would question not only the theoretical premises of modernisation theory and the Law and Development movement ${ }^{79}$, but also the results that had been seen since their application, which, broadly speaking, range from the integration of customary law into legal systems built from scratch, although Westernised in technical and legal terms, to the attempt to abolish customary/traditional law tout court ${ }^{80}$.

${ }^{79}$ By way of example, see SAMUEL P. HunTINGTON: "It is false to believe that tradition and modernity "are mutually exclusive". Modern society is not simply modern; it is modern and traditional." in HUNTINGTON 1971, 295.

${ }^{80}$ In detail, proposed a typological and conceptual model for analysing the different types of relationship between formal and informal systems of justice, vide FORSYTH 2009, 201 et seq. Regarding the attempt to abolish customary/traditional law, it is important to mention the Mozambican example, which, post-independence, was focused on its total suppression, in a process of socialist modernisation carried out by the FRELIMO government. This is a particularly relevant example as Mozambique was the host country, during the 24 years of the Indonesian invasion, to some of the leaders of FRETILIN, the historical Timorese party, and the party which would have had governmental responsibilities in the transition and immediately after Timor-Leste's independence. For a good starting point for further reading, vide BEUMAN 2016, 35 et seq. It should also be noted that when the Republic of Indonesia incorporated the territory of Portuguese Timor - as its 27th Province; Timor Timur - application of Law No. 5 of 1974 concerning the Regional Government was extended to it (Undang-undang no. 5 tahun 1974 tentang pokok-pokok pemerintahan di daerah, UU 5/1974). This was later complemented by Law No. 5 of 1974 on the governing of villages/towns (Undang-undang no. 5 tabun 1979 tentang pemerintahan desa, UU 5/1979), which led to standardisation of a Javanese administrative model, which, in its unifying project, went on to prohibit the existence of traditional institutions other than those adopted, or rather, recognised at the national level by the Indonesian parliament.

The direction of this policy would have consequences for the traditional social fabric, its leadership and, of course, the legitimacy of its Law. Vide BRÄUCHLER 2010, 7. 
It should be noted, however, that the reaction to the model that preceded legal pluralism, which was widely criticised in academia ${ }^{81}$, alongside the dynamism and youth of its early practitioners, has meant that the renaissance of legal pluralism has been seen as something tending to be positive, although, as BOAVENTURA DE SOUSA SANTOS noted, there is nothing "inherently good, progressive or emancipatory about "legal pluralism"" 82 .

It is precisely this ambivalence inherent in legal pluralism - as a programme - that must be explored. On one hand, it can be understood as a way of framing and facilitating the existence of specific legal cultures which are, themselves, in various quarters, the only means available for resolving disputes and maintaining order within communities. On the other hand, legal pluralism can be used by groups which, due to various factors, exercise domination, control and subjugation of others in this way, promoting various models of justice, which will tend to be unfavourable to the subjugated populations, thus increasing social imbalance.

Another aspect worthy of reflection, when there is the ontologicalsystematic separation characteristic of strong legal pluralism, relates to the different and sometimes contradictory loyalties and duties to which individuals are subject in the plural framework of normative systems. In this sense, see the excerpt below regarding the Timorese situation:

"Researcher: Senhor A., may I ask you a "stranger" question?

Chefe de Suku: You bave lived in our village for almost three years and I am used to your questions. You are welcome. I will try to answer.

${ }^{81}$ By way of example, vide TRUBEK and GALANTER 1974.

82 SANTOS and TRINDADE 2005, 53. 
Researcher: Imagine, you are walking along a road, and at a junction this road splits up into three different paths. And now your governo says, "Turn left!" And the Church says "go straight!" And your tradition requires you to turn right! Where would you go?

Chefe de Suku: You must respect all three.

Researcher: Yes. But sometimes in life there are these difficult situations and you must make decisions [...].

Chefe de Suku: We really must respect the governo in Dili, the religion katoliko [catholic religion] and our tradisaun [traditions] - but if the situation is really, really hard, I think, I can never do anything against my sacred house. Everybody must respect the lisan [traditional law]"83.

By reproducing this dialogue, we aim to illustrate not only the simultaneous existence of various normative dimensions and the implications of these, which paradoxically tend to become - from an individual perspective intertwined within the framework of strong pluralism, but also the difficulties experienced in the context of multiple affiliations, such as those presented here, in line with the definition of legal pluralism proposed by JACQUES VANDERLINDEN, who states: "[...] pluralism is essentially a condition, thus a way of being, of existing. It is the condition of the person who, in his daily life, is confronted in his behaviour with various, possibly conflicting, regulatory orders, be they legal or non-legal, emanating from the various social networks of which he is, voluntarily or not, a member ${ }^{2} 84$.

According to some critics of legal pluralism, the situation described above fosters normative relativism, since it places various legal, ethical and moral

83 LOCH apud CABASSET and DURAND 2009, 95.

84 VANDERLINDEN 1989, 153-154. 
realities on the same level, which, as we have seen, may ultimately be subsumed by manifestations of the legal ${ }^{85}$.

Beyond a sociology of law analysis, and in the context of a programmatic vision of legal pluralism, a number of criticisms have been raised that fall within the field of Philosophy and the Theory of Law, concerning in particular a putative model of justice proposed by legal pluralism. Nevertheless, in terms of a theoretical reflection, in defining the scope of our analysis, this is not a subject on which we should focus here, principally because we understand legal pluralism - and here we accept less favourable assessments of this position - as the description of a fact, as a phenomenological reality that relates to the simultaneous existence of various normative realities ${ }^{86}$.

In our view, only an individual analysis of each of these criticisms, within a comparative methodological approach, could address concerns of justice, which, as we have argued, we consider to be beyond the scope of our analysis. To quote MARTTI KOSKENNIEMI, legal pluralism "cannot sustain a project of law in its own right" ${ }^{\prime 87}$. The question we raise - particularly with regard to classical pluralism - is: but is this its vocation, its objective?

85 In that sense, LAURA GRENFELL, invoking the contributions of MALINOWSKI and EHRLICH, who state that "all binding obligations should be considered law and that: "the law is an ordering", raised the point that, in the case of deep legal pluralism, "the boundaries between law, legal culture and societal tradition are left unclear" in GRENFELL 2013, 66.

86 A different but not insignificant question, namely for the future development of broader and deeper studies on legal pluralism, is that concerning the value of customary law at trial and its consequences: whether as a matter of fact, which must necessarily be proved by the party invoking it, or as a matter of law, which the court, a quo, may know of its own motion.

${ }^{87}$ KOSKENNIEMI apud GRENFELL 2013, 66. 


\section{INTERNATIONAL DEVELOPMENT AND LEGAL PLURALISM: FROM INDUSTRY TO NEW PARADIGMS.}

The renaissance of legal pluralism, both in its factual and programmatic dimensions, emerges, as we have said, with the demise of modernisation theory $^{88}$ - and, consequently, of the Law and Development movement simultaneously exposing many of the gaps and limitations of these. LAURA GRENFELL, in the spirit of the aforementioned study by DAVID TRUBEK and MARC GALANTER, states "the demise of the [Law and Development movement] can be traced partly to its failure to examine or understand the dynamics of the relationship between legal pluralism and the rule of law in the developing world" 89 .

88 Although beyond the scope of this presentation, it should be noted that the theoretical and practical void left by obsolescence - in the restricted context referred to above - of modernisation theory would not be filled by the conceptual model of legal pluralism. Both are rooted in different fields of analysis, with different premises and programmatic objectives, as is clear from the presentation made. Thus, this void would be filled by a theoretical current, also on a programmatic basis, which, with some success, would be imposed, namely in Latin America: dependency theory. This, in contrast, would present a markedly Marxist framework, moving away from the theoretical models that we have noted. Thus, in short, "dependency theory argued that the sources of underdevelopment were to be found in the history and structure of the global capitalist system." in TAMANAHA; 1995, 477. We will not dwell here on the various models put forward and the consequences they would have; for such, vide SNYDER 1980 and GREENBERG apud CARTY 1980, 89-119. Nevertheless, we consider it relevant to point out that the explanatory framework of dependency theory, even though, like any Marxist theory, it tends to undervalue the role of the Law, would still indelibly mark various currents of legal pluralism - even by its detachment from the Marxist orthodox view of the role of the Law in society - which tend to be, in our view, more radical in terms of their objectives, observing, in comparison, a substantial difference between the Western legal pluralism and that of the Latin American framework. Vide WOLKMER 2001; BRANDÃO 2015.

${ }^{89}$ GRENFELL 2013, p. 23. 
In this sense, although, at the theoretical level, there was still a small amount of scientific production and, at the practical level, some projects continued to exist, having survived at the expense, often, of parallel interests of donor countries, the fact is that "[modernization] theory was no longer convincing, and it seemed even difficult to imagine a future in which modernization theory could again play a dominant role within macro-sociological theorizing. But in the mid-1980s such a new future for modernization theory emerged"

The re-emergence of modernisation theory in the mid-1980s - which WOLFGANG KNÖBL refers to as "old wine in new bottles" - occurred in a global context marked by substantial changes in the business world, with the idea of globalisation becoming increasingly accentuated, reflecting an ever larger and more comprehensive commercial network. Through the Asian Tigers ${ }^{91}$, whose increasing economic power was undeniable, this network had now been extended, through the contagion effect/chain of dependency, to a substantial number of emerging or developing countries.

International Development - mirroring the political and economic needs of the countries concerned - now called for greater economic and trade integration, using old models of course, thus renewing some of the premises of modernisation theory, namely institutional isomorphism - both economic and political - a model which, to some extent, the success of some of the countries of the Asian economic miracle confirmed.

Although there is no direct positive correlation in itself, the Soviet economic slowdown, which would lead at the end of the decade to the collapse of the USSR, would nevertheless cause the programmatic nature of Western development theories to begin to mutate and take on a more poignant form

${ }^{90}$ KNÖBL apud DELANTY and IsIN 2003, 104.

${ }^{91}$ Hong Kong; South Korea; Singapore and the Republic of China/Formosa. Of note, also, the contagion effect, in particular by means of imports, that the economic acceleration of these countries would have throughout the region. 
- under the aegis of neo-liberalism; the legacy of the Chicago School, of the administrations of Ronald Reagan and of the governments of Margaret Thatcher - the victorious epistemological framework, that is, development based on state-building for the export of a liberal democracy openly based on a capitalist, neo-liberal mode ${ }^{2}$.

Conceptually, and replacing the Law and Development movement, the response to new needs would arise by means of the rule of law: "The concept is suddenly everywhere - a venerable part of Western political philosophy enjoying a new run as a rising imperative of the era of globalization" "93. Sufficiently flexible and ambiguous, in its defining elements ${ }^{94}$, it would be the ideal vehicle to bring together concepts such as democratisation; human rights and, of course, free-market capitalism ${ }^{95}$. In fact - and as a consequence of a world which had become less ideological with the end of the Cold War - the rule of law tended to be seen, or rather, promoted, paradoxically as a "a nonideological, even technical solution" 96 .

The political and economic developments of the new decade would be based on it, in the area of development and of countries with justice systems in transition ${ }^{97}$, and, in the light of the particularly rich events of the 1990s, a change of approach would be seen in Official Development Assistance, but also

92 "[...] creating a new development paradigm with important implications for the law reform agenda. It implied a triple shift, from state to market, from internal to export-led growth, and from official capital flows to private foreign investment." in TRUBEK and SANTOS 2004, 83.

${ }^{93}$ Carothers 2006, 3; 19 et seq.

${ }^{94}$ Referring to modernisation theory and dependency theory, and demonstrating that which we have stated, BRIAN TAMANAHA suggests: "The rule of law can work with either theory, or with a combination of both, or with most any economic theory and with various political arrangements", and cites JOSEPH RAZ stating that the rule of law "is even compatible with nondemocratic systems". Vide TAMANAHA 1995, 484.

95 GRENFELL 2013, 24 et seq.

96 CAROTHERS apud GRENFELL 2013, 25.

${ }^{97}$ In particular those, from the Eastern bloc, which, now reacquiring their independence, embarked on wide-ranging reforms, based on the rule of law, with a view to democratisation. 


\section{Miguel de Lemos ILEGAL PLURALISM AND INTERNATIONAL DEVELOPMENT I ISSN 2675-1038}

the emergence, through the involvement of International Financial Institutions - such as the World Bank, the IMF or the $\mathrm{IFC}^{98}$ - of a billiondollar industry dedicated to international development projects, relating in particular to state-building and the rule of law.

In the somewhat ironic words of DAVID TRUBEK, "Aid agencies like the World Bank, which once focused primarily on building roads and dams, and getting macroeconomic variables right, now proclaim the importance of the "rule of law" (ROL) and spend billions to reform the legal systems of countries [...]"'99.

Thus, as a result of the revival of modernisation theory, even if cloaked in other robes - those of the rule of law - a revived theoretical reflection - of a macro-sociological framework - would emerge among academics, within the scope of which, particularly in the USA, attempts would be made to reintroduce "a modified concept of differentiation which takes into consideration the actions of groups and social movements and their oftentimes contingent results". For their part, continuing along the lines of WOLFGANG KNÖBL's descriptive relationship, the European sociologists, and especially ULRICH BECK and ANTHONY GIDDENS, "were heading towards a new description of modernization processes they called "reflexive modernization", thus indicating that the process of modernization is not a simple story of progress but one in which risks can be found"100.

98 International Finance Corporation: IFC. For a global vision of the architecture of the system, vide SARKAR 2009.

99 TRUBEK and SANTOS 2004, 81. Along the same lines, quantitively: "In the 1990s, there was a massive surge in development assistance for law reform projects in developing and transition countries. These projects involve investments of many billions of dollars. The World Bank alone reports it has supported 330 "rule of law" projects and spent \$2.9 billion dollars on this sector since 1990. At the beginning of this new surge of interest in law within the development community, there appeared to be a broad consensus on the reasons to create the "rule of law" in these transitional and developing economies, on what the "rule of law" meant, and on the best strategies to implement those objectives." Idem, 74.

100 KNÖBL apud DELANTY and ISIN 2003, p. 105. 
The attempt to exceed the models created decades before is clear, although "most of the arguments now being pushed forward to formulate a new concept of differentiation and to build a new theory of modernization have already being tried in the past ${ }^{101}$, leaving these new conceptions exposed to the same practical vulnerabilities, and theoretical criticisms, that their predecessors were previously faced with.

This not only demonstrates the vitality of the old modernisation theory, but also makes it legitimate to question, given the above, whether a new conceptual paradigm for modernisation has, in fact, been achieved.

This is due, namely, to the conceptualisation of the various development projects relating to justice systems drawn up in the 1990s which, under the aegis of the rule of law - for export - would continue, as in previous decades, to be based on a formalist and instrumental vision of law - leading, through the application of the diffuse concept of best international practice, to standardisation of the various national legal systems - redirecting the democratic rule of law, namely in emerging countries, to the operationality of the judiciary, namely to its independence; to the possibility of enforcing sentences; to the predictability of the law and the possibility of its applicability ${ }^{102}$, with a view, mainly, to fostering a good business environment and economic development. ${ }^{103}$ The rule of law would be seen, in those terms, adjectively, "[...] as a necessary ingredient in any development strategy" ${ }^{\text {"104 }}$.

In the light of the above, we are witnessing a revisiting - if ever we departed from such a model - of the Weberian state-centric framework, once again considered as the foundation of the entire development system, relegating,

\section{Idem.}

102 TAMANAHA, SAGE and WOOLCOCK 2012, 42.

103 Vide, in particular on the World Bank's view regarding the rule of law, SHIHATA 1991.

104 TRUBEK and SANTOS 2004, 74. On the demystification of this claim, giving the examples of China and Japan, where the contribution of the Western framework of the rule of law for their development is insipient, UPHAM apud CAROTHERS 2006, 75 et seq. 
in its practical application, both intermediate civil society organisations and the cultural and customary realities of the societies targeted for intervention, to the margins of these programmes ${ }^{105}$.

It should be noted that, as we have mentioned, the rule of law of the 1990s is, in itself, a product of its time, focused, in this phase of post-Cold War distension, on a standard economic model to be exported globally, through capital markets and the increasingly intertwined commercial networks. Nevertheless, this economic model is only one of the components bundled with the concept of the rule of law. In its export aspect, despite its simplistic nature, it also included, as we have seen, the programmatic component relating not only to democracy but also to human rights. Perhaps here we may note, in greater detail, the difference between the rule of law programme and the Law and Development movement.

Even if the latter was, in its genesis, also a project focused on democratisation - through the export of a socio-political model - the fact is that the approach to this programmatic aspect would have to be through intermediate means, in the sense that "[...] growth and cultural transformation would lead to democracy and protections of human rights". Despite this, we would say, extremely optimistic, view, "this "spillover" would not occur automatically: human rights had to be pursued as an independent goal"106.

It would be precisely this proactive model that was pursued, even if the aforementioned spillover - the repercussions - namely within the scope of rule of law projects, should be seen as contaminating these new components - democratisation and buman rights - by the functional logic of promotion of the rule of law in its economic aspect, and not the opposite. Thus, as BRIAN TAMANAHA notes, while the spread of capitalism brought about several consequences in the emerging countries' societies, changes he calls side effects

105 GRENFELL 2013, 26.

106 TRUBEK and SANTOS 2004, 84. 
rather than intended objectives, tout court, of global capitalism, it being, in this sense, a more technical and culturally neutral model, on the other hand he states that, "by contrast, human rights and women's rights initiatives directly target the culture, society, and policy when challenging harsh or discriminatory treatment of low caste, the poor, children, women, or social outcasts (homosexuals, criminals, and so forth)" 107 .

It is in this context that, gradually over the decade, culminating in the turn of the century, we would see a change in the approach of international development, beginning a process of promoting a more holistic vision of its projects, with the rule of law becoming an objective in itself and not a mere auxiliary instrument to achieve other purposes ${ }^{108}$.

This change was due to the lack of success of the neo-liberalisation projects, the implementation of which destroyed - despite everything, the premise of less State needs some kind of State, which, in certain fragile or emerging realities, is not the case, and we can see an almost total absence of institutions ${ }^{109}$. On the other hand, methodologically, while that model proved to have been exhausted in relation to economic and institutional development, there was a glaring discrepancy between the objectives of

107 TAMANAHA, SAGE and WOOLCOCK 2012, 43.

108 LEE 2017, 422-423.

109 According to data of the World Bank - World Development Report, 2011 -, It is estimated that the countries best equipped to receive rule of law projects take about 41 years to achieve these objectives. It should also be noted that the same study omits information on fragile states and suggests the term "infinity" for the implementation of these objectives. In an analysis of this study by LANT PRITCHETT and FRAUKE DE WEIJER the authors state: "in this indicator the time to reach the threshold at either the fragile states' rate of progress or that of the average non-fragile country is infinity as, on average, there has been zero progress" in PRITCHETT apud GRENFELL 2013, 32. 


\section{Miguel de Lemos ILEGAL PLURALISM AND INTERNATIONAL DEVELOPMENT I ISSN 2675-1038}

democratisation and of the promotion of human rights and their results, which in most cases were practically non-existent ${ }^{110}$.

In the words of THOMAS CAROTHERS - who always brings us an empirical and practical perspective - "In the broader field of democracy assistance, the pattern has been for democracy promoters to translate the overarching idea of democracy into an institutional checklist or template that they can pursue through a series of specific aid initiatives. Similarly, rule-of-law promoters tend to translate the rule of law into an institutional checklist, with primary emphasis on the judiciary" 111 . In other words, we are once again dangerously close to the prêt-à-porter type - a unique model in which, by imposing measures and objectives, local realities and cultures are relegated to second place and, should these perhaps be recognised - in a situation already seen before - they are described as barriers or obstacles that must be overcome, in the name of development - in all the frameworks referred to above.

Thus, at the end of the decade - and we may note, ironically, the cyclical nature of the reality shaping our work - one begins to question the framework of such programmes, in particular due to their formalism, the export/transplantation of models and the autism of the development agencies and international financial institutions vis-à-vis specific socio-cultural contexts. In other words, "after the disappointing outcomes of many years of legal and judicial reform, and in view of the enormous challenges posed by state building in numerous fragile and failed states, ID A's [International Development Agencies] are beginning to accept that governance and justice mechanisms that operate either outside the framework of the state or in the fringes between state and society-non-state justice systems

110 SANTOS, apud TRUBEK and SANTOS 2004, 254. We may note, following YONG-SHIK LEE, the need, when implementing development projects, to prioritise their elements, in particular when resources are limited. LEE 2017, 429-430.

111 Carothers 2006, 20. TrubeK and Santos 2004, 90. 
[...] - are indispensable components of reform processes aimed at improving the overall performance of legal and judicial institutions" $"$ ".

Álvaro SANTOS, in the work we have cited, presents a detailed picture of the change of perspective that would occur in the World Bank's conceptualization, and that would contaminate other international development agencies through, in particular, new theoretical perspectives, among which we may highlight those of AMARTYA SEN ${ }^{113}$. SEN proposed a bolistic vision of development - as we have noted -, "emphasizing non-economic values believed to enhance human life", arguing that the rule of law was one of the key elements for development, and that development should also promote "political freedom, economic choice, and protection from abject poverty"

Therefore, from a formalist approach, we have witnessed the transition to a substantive understanding of local realities. Thus, "A new conventional wisdom about the rule of law and development seems to have taken root in development circles. It is asserted that formalist rule of law, which stresses institutionalized legal mechanisms and absolute autonomy from politics, is a necessity for economic development. But attempts to transplant formalist rule of law to developing and/or democratizing countries could actually be counterproductive for economic, institutional, and political development, especially when informal mechanisms would be more effective and efficient" $" 115$.

112 FAUNdeZ apud TAMANAHA, SAGE and WOOLCOCK 2012, 177.

113 Vide, among others, SEM 2003 and SEM 2009, 12 et seq.

114 LEE 2017, 428-429. It should be noted, following the author, that at the same time the United Nations Development Programme had introduced in its documents and metrics the concept of "human development", mirroring, of course, this holistic vision of development. Vide UNDP; What is Human Development?; available at: http://hdr.undp.org/en/humandev.

115World Bank, Legal Institutions of a Global Economy Homepage, http://www1.worldbank.org/ publicsector/legal/index.htm. apudTRUBEK and SANTOS 2004, 90 . 
It was in this context of an evolution in the models for implementing official development assistance that Timor-Leste became independent in 2002, and the projects implemented there, namely during its first decade of existence, would be affected by the heterogeneity inherent to a paradigm in transition, between frameworks that were already established and those that were now trying to impose themselves.

In this sense, following LAURA GRENFELL, "from 2002 onwards the World Bank has recognised that in some contexts it may be beneficial for informal norms and mechanisms to supplement, and sometimes supplant, formal law" "116. It should be reiterated that the failure of development projects, as far as the law and justice systems are concerned, stems neither from the technical incapacity of their implementers ${ }^{117}$ nor from a lack of financial resources, which, as we have already noted, were and are abundant. The failure, it can be understood today, this being a position we share, is conceptual in nature, and is particularly a question of what a technical cooperation project for development is or what it should be $e^{118}$.

In our view, the key to the new paradigm of development projects is that they must be designed in such a way as to reconcile the unavoidable formalism inherent to a technical framework project with an approach that is necessarily ad hoc and capable of understanding and adapting to local realities and specificities, as well as anticipating the idiosyncrasies of dialogue with the pluralist frameworks of the normative environments of these societies. This is also because, and this cannot be overstated, development projects such as those we have noted are themselves enablers of legal pluralism, thus corresponding to another normative layer and opening doors to others, by means of international legal instruments. The logical impossibility proposed by

116 GRENFELL 2013, 27.

117 Despite the questions raised by THOMAS CAROTHERS, who does not always give a positive impression of these technicians. CAROTHERS 2006; passim.

118 GLENN apudTAMANAHA, SAGE and WOOLCOCK 2012, 96. 
technical cooperation projects, namely within the framework of the Law and Development movement, or in the first phase of the expansion of the rule of law, of rejecting a reality that they themselves created or enabled, is therefore somewhat paradoxical.

\section{REFERENCES}

Albrecht, P.; KYED, H., Justice and Security: When the State Isn't the Main Provider, Copenhagen, 2010.

APTER, D., Rethinking Development: Modernization, Dependency, and Post-Modern Politics; Newbyry Park, 1987.

ARNSCHEIDT, J.; ROOIJ, B. VAN; OTTO, J.M. (Ed.), Lawmaking for Development - Explorations into the theory and practice of international legislative projects; Leiden, 2008.

BEndA-Beckmann, F., "Who's Afraid of Legal Pluralism?”, The Journal of Legal Pluralism and Unofficial Law, 34:47, 2002.

Benton, L. Law and Colonial Cultures: Legal Regimes in World History, 1400 1900, Cambridge, 2002.

BERnsteIN, H., "Modernization theory and the sociological study of development", The Journal of Development Studies; 7:2, 1971.

Bingham, T., The Rule of Law, London, 2011.

BrÄUCHLER, B., "The Revival Dilemma: Reflections on Human Rights, Self-Determination and Legal Pluralism in Eastern Indonesia", The Journal of Legal Pluralism and Unofficial Law, 42:62, 2010.

Brown, M., "Formação do Estado e da comunidade política em TimorLeste: A centralidade do local", Revista Crítica de Ciências Sociais, Lisbon, 2014. 
Cabasset, C.; Durand, F. (ed.), East Timor: How to Build a New Nation in Southeast Asia in the 21st Century?, Bangkok, 2009.

Cane, P.; Conaghan, J. (ed.), The New Oxford Companion to Law, Oxford, 2008.

Carothers, T. (ed.), Promoting the Rule of Law Abroad - In Search of Knowledge, Washington, 2006.

Creveld, M., The Rise and Decline of the State, Cambridge, 1999.

DELANTY, G.; IsIN, E. (eds.); Handbook of Historical Sociology, London, 2003.

Dupret, B.; Berger, M.; AL-Zwaini, L. (ed.), Legal Pluralism in the Arab World, The Hague, 1999.

FORSYTH, M., A bird that flies with two wings: the Kastom and State justice systems in Vanuatu, Camberra, 2009.

Friedman, L., “On Legal Development”; Rutgers Law Review; 24, 1969.

GARDNER, J. A., Legal Imperialism - American Lawyers and Foreign Aid in Latin America, Madison, 1980.

Grenfell, L., "Promoting the rule of law in Timor-Leste", Conflict, Security \& Development, 9:2, 2009.

Grenfell, L., Promoting the Rule of Law in Post-Conflict States, Cambridge, 2013

GRIFFITHS, J., "What is Legal Pluralism?", The Journal of Legal Pluralism and Unofficial Law, 18:24, 1986.

HoHe, T.; NIXON, R., Reconciling Justice: 'Traditional' Law and State Judiciary in East Timor, Washington, DC, 2003.

HoOker, M.B., Legal Pluralism. An Introduction to Colonial and Neo Colonial Laws, Oxford, 1975. 
Hoselitz, B. (ed.), The Progress of Underdeveloped Areas, Chicago, 1963.

Huntington, S. P., "The Change to Change: Modernization, Development and Politics”, Comparative Politics; vol. 3; n. 3, 1971.

JENnINGS, I., The Approach to Self-Government, Cambridge, 1956.

KÖNZ, P.; PARrY, C.; SHINDY, W., "Legal Development in Developing Countries", Proceedings of the American Society of International Law at Its Annual Meeting, vol. 63, 1969.

LEGRAND, P., “The Impossibility of 'Legal Transplants.", Maastricht Journal of European and Comparative Law, 4(2), 1997.

Lemos, M. de, A Autodeterminação do Timor Português no contexto da Guerra Fria, Thesis submitted for the degree of Master of Law, University of Lisbon, Lisbon, 2018.

MAYHEW, L., "In defence of Modernity: Talcott Parsons and the Utilitarian Tradition", The American Journal of Sociology, 1984.

MEARnS, D. J., Looking Both Ways: Models for Justice in East Timor, Sydney, 2002.

MELISSARIS, E., Ubiquitous Law - Legal Theory and the Space for Legal Pluralism, Farnham, 2009.

Meneses, M. P.; GraÇA, J., Para uma Justiça de Mariz Timorense: o contributo das justiças comunitárias; Díli, 2017.

Merry, S. E., "Legal Pluralism", Law \& Society Review, Vol. 22, n. o 5, 1988.

Mommsen, W.J; De MoOr, J.A. (Ed.), European Expansion and Law - The Encounter of European and Indigenous Law in $19^{\text {th }}$ and $20^{\text {th }}$ Century Africa and Asia, Oxford, 1992. 
Nisbet, R. A., Social Change and History - Aspects of the Western Theory of Development, New York, 1969.

PARSOns, T., Talcott Parsons on institutions and social evolution - Selected Writings; Chicago, 1982.

PARSONS, T., The social system, Londres, 2005.

PIRES, F., "Fontes do Direito e Procedimento Legislativo na República Democrática de Timor-Leste"; Estudos em Memória do Professor Doutor António Marques dos Santos II, Coimbra, 2005.

RAZ, J., "Why the State?", King's College London Dickson Poon School of Law Legal Studies Research Paper Series; Paper n. ' 2014-38, 2014.

SACK, P.; MinCHIN, E., Legal Pluralism Proceedings of the Canberra Law Workshop VII, Canberra, 1985.

SANTOS, B. de S., "Law: A Map of Misreading. Toward a Postmodern Conception of Law", Journal of Law and Society, Vol. 14, N. ' 3, 1987.

SANTOS, B. de S.,; TRINDADE, J., Conflito e Transformação Social: Uma Paisagem das Justiças em Moçambique I, Porto, 2005.

SANTOS, B. de S.,; VAN DúnEN, J., Sociedade e Estado em Construção: Desafios do direito e da democracia em Angola I, Coimbra, 2012.

SEINECKE, R., "Rechtspluralismus in der Rechtsgeschichte", Zeitschrift des Max-Planck-Instituts für europäische Rechtsgeschichte, N. ${ }^{\circ}$ 25, 2017.

Silva, V. P. da, Para um Contencioso Administrativo dos Particulares - Esboço de uma teoria subjectivista do recurso directo de anulação, Coimbra, 2005.

Swenson, G., "Legal Pluralism in Theory and Practice", International Studies Review, n. ${ }^{\circ}$ 20, 2018.

Tamanaha, B. Z., "Understanding Legal Pluralism: Past to Present, Local to Global”, Sydney Law Review, Vol. 29, 2008. 
Tamanaha, B. Z., On the Rule of Law - History, Politics, Theory, Cambridge, 2004.

TAmanaha, B. Z.; SAGE, C.; WoOlCock, M., Legal Pluralism and Development - Scholars and Practitioners in Dialogue, Cambridge, 2012.

Tamanaha, B. Z., "The Lessons of Law-and-Development Studies", The American Journal of International Law, Vol. 89, n. ${ }^{\circ}$ 2, 1995.

Truber, D. M.; SAntos, A., The New Law and Economic Development: A Critical Appraisal, Cambridge, 2004.

TrubeK, D.; Galanter, M., "Scholars in Self-Estrangement: Some Reflections on the Crisis in Law and Development Studies in the United States", Wisconsin Law Review, 1062, 1974.

VAnderlinden, J., "Return to Legal Pluralism - Twenty Years Later", The Journal of Legal Pluralism and Unofficial Law, 21:28, 1989.

VAnderlinden, J., Pluralismes juridiques, Brussels, 2013.

WeBER, M., The Theory of Social and Economic Organization, Nova Iorque, 2012.

Wolkmer, A., Pluralismo Jurídico - Fundamentos de uma Nova Cultura no Direito, São Paulo, 2001. 